\title{
Scripture, Time, and Authority among Early Disciples of Christ
}

\author{
Seth PerRy
}

This article explores the relationship between the idealization of the Bible and the material characteristics of printed bibles among the Disciples of Christ in the early nineteenth century. The Disciples were founded on the principles of biblical primitivism: they revered the "pure" Bible as the sole source for proper faith and practice. The tenacity with which Disciples emphasized their allegiance to an idealized, timeless Bible has obscured their attention to its physical manifestations and use as printed scripture. The timeless authority of the Bible was entangled with the historical contingencies of mere bibles, and the ways in which they dealt with these tensions offer important perspective on nineteenth-century bible culture. Scholars have treated primitivism as an ahistorical impulse-the idealization of the New Testament church as a mythical sacred era outside of time that could be perpetually inhabited. By contrast, through an examination of the New Testaments edited and published by Disciples leader Alexander Campbell and the heavilyannotated preaching bible of Thomas Allen, an early Disciples preacher, I argue that in seeking to recover the New Testament era through historicized understandings of scripture, primitivists like Campbell and Allen situated the early church itself firmly within historical, not primordial, time.

God's book is, however, put into the hands of men, as it was first spoken to men; but they have, by some unpropitious cause, been taught not to receive it from God, but from men. They do not consider, that the written book as well as the spoken word, is tendered to us under the stipulations of human language-according to the contract between man and man, touching the value or meaning of the currency of thought: that every word and sentence is to be weighed and tested, by the constitutional laws and standards of the currency of ideas.

Alexander Campbell, $1835^{1}$

The author would like to thank the editors and anonymous readers at Church History for their helpful comments; Catherine Brekus, Clark Gilpin, and Richard Rosengarten for reading an early version of this article; and B.M. Pietsch for reading a late one.

${ }^{1}$ Alexander Campbell, A Connected View of the Principles and Rules by Which the Living Oracles May Be Intelligibly and Certainly Interpreted. (Bethany, Va.: M'Vay and Ewing, 1835), 16.

Seth Perry is Assistant Professor of Religion in the Americas at Princeton University. 
B IBLICAL primitivism was a hallmark of early-national American protestantism. The period saw a number of groups coalesce around various leaders arguing essentially the same ideas: that the existing churches had departed, in belief and practice, from the ecclesiastical model established by Christ, and that the Bible should be re-established as the sole authority for Christian practice. Two major threads of this movement, led by Barton W. Stone (1772-1844) and Alexander Campbell (1788-1866), united in the early 1830 s to form what became known as the Disciples of Christ. Stone and Campbell argued that "priests" and theologians had replaced the simple truths communicated by God with elaborate schemes of their own devising, interspersing human authority between Christians and scripture. Their remedy was a set of twin commitments: to the plain Bible as the proper source of authority for Christian faith and practice, and to the right and responsibility of individual Christians to access that source of authority directly, for themselves. John Allen Gano, who converted to Stone's movement in the $1820 \mathrm{~s}$, found the two commitments inseparable, as scripture itself enjoins the individual's capacity and freedom to access its truth: "To the Bible I looked as the polar star to direct me; common sense and all the Scripture with which I was acquainted taught me to join, where I could read, think, believe and obey the Truth for myself, untrammeled by any Creed, Confession of Faith, Church Rules or any other Book or System merely of human invention." 2

These commitments generated a preoccupation with the Bible's printed form which has been widely overlooked. The tenacity with which Disciples emphasized their allegiance to an idealized Bible has obscured their attention to its physical manifestations and use as printed scripture. For the Disciples, as much as any other group, the timeless authority of the Bible was entangled with the historical contingencies of mere bibles, and the ways in which they dealt with these tensions offer important perspective on nineteenth-century bible culture. Attending to Disciples' negotiation of the material and the abstract with respect to the Bible raises important questions about early-national primitivism itself. Scholars have treated primitivism as an ahistorical impulse - the idealization of the New Testament church as a mythical sacred era outside of time that could be perpetually inhabited. By contrast, I argue here that in seeking to recover that era through historicized

\footnotetext{
${ }^{2}$ Journal of John Allen Gano, University of Kentucky Archives. For the context of primitivism in the early nineteenth century, see Nathan Hatch, The Democratization of American Christianity (New Haven, Conn.: Yale University Press, 1989), esp. 68-81; Douglas A. Foster, ed., The Encyclopedia of the Stone-Campbell Movement (Grand Rapids, Mich.: Eerdmans, 2012) is an excellent source on the Stone-Campbell movement and its significance in the history of Protestantism in America.
} 
understandings of scripture, primitivists like Campbell situated the early church itself firmly within historical, not primordial, time.

Disciples evinced an idealizing abstraction of scripture - they imagined the Bible as an inviolate, timeless source of truth. Stone drew the distinction between theological argument and biblical reliability explicitly: "I pay deference to the judgment of great and pious men who have lived before us, or contemporary with us. But great and good men have differed. Therefore from the Bible I wish to draw my sentiments, and by the Bible to have them judged." 3 Here, Stone opposes the complicating disagreements of history - "men have differed"- with the Bible's univocal authority in a perpetual present. Such idealized purity mixes poorly with the necessity of printed texts, though. The granting of revelation might be a divine prerogative, but printing it is definitely human: the idealized Bible can be singular and unchanging in its abstractness, but material bibles are subject to the historicizing and diversifying effects of, among other things, collation, translation, editing, and publishing.

Here, I will investigate early Disciples' approach to the inevitable materiality of scripture through six material artifacts: five editions of the New Testament edited and published by Alexander Campbell between 1826 and 1835 and the personal bible of Thomas M. Allen (1797-1871), a convert of Stone's and a widely-known Disciples minister in Kentucky and Missouri during the 1830s and 1840s. Campbell was a conflicted bible editor: he was fully committed to a belief in the transparent simplicity of scripture, but also convinced that the meaning-making power of a bible's paratextual, extrascriptural, content was anything but simple. ${ }^{4}$ Allen's personal bible, on the other hand-a duodecimo Authorized Version published by Silas Andrus of Hartford, Connecticut, in 1828, now held by the University of Chicago-is covered in handwritten notes, an artifact of an individual reader's efforts to interpret the Bible for himself. Allen's notes demonstrate the layers of paratextual and textual authority that went into reading the "Bible alone," including his use of Campbell's New Testament. Together, these objects are a fascinating window on early Disciples' negotiation of the distance between the ideal Bible and the bibles of material experience, and they shed new light on the conception of historical time that primitivist commitments demanded.

\footnotetext{
${ }^{3}$ Barton W. Stone, An address to the Christian churches in Kentucky, Tennessee, \& Ohio on several important doctrines of religion (Nashville, Tenn.: M. \& J. Norvell, 1814), 5.

${ }^{4}$ Genette Gérard, Paratexts: Thresholds of Interpretation, trans. Jane E. Lewin. (Cambridge: Cambridge University Press, 1997).
} 


\section{Alexander Campbell and the Bible's Complicated Simplicity}

Alexander Campbell embodied the Bible-alone ethos in the early-national period. ${ }^{5}$ It would be difficult to find a greater obsession with the idealized Bible among his contemporaries. However, Campbell's insistence on the simplicity of scripture was only one aspect of his complicated approach to the Bible as printed word. His very confidence in the unique authority of the Bible and in believers' ability to read, understand, and apply it to proper Christian practice forced Campbell to confront the challenges of its presentation. Although he is remembered for urging the common sense reading of scripture, close analysis of Campbell's bible-editing work demonstrates that he recognized multiple contingencies leading up to an individual moment of common-sense reading, conditions which had to be met and controlled in order to give the common reader the opportunity to read plainly. These conditions were to be met by an editor who compiled a correct text, presented it in the appropriate manner, and constructed a paratextual apparatus for it - a framework of materials such as prefaces, annotations, and appendices that would assist and encourage reading. Campbell held the Bible in too high esteem not to recognize that the pure access to it he sought for his followers would have to be facilitated by learned mediation, but his insistence on the self-sufficiency of scripture led him to downplay that role even as he found it necessary.

Campbell's New Testament was first published in 1826 as The Sacred Writings of the Apostles and Evangelists of Jesus Christ, Commonly Styled the New Testament. It was part of a flurry of more or less unsuccessful challenges to the dominance of the King James Version in the early nineteenth century. Although it is unlikely that The Living Oracles, as the volume became commonly known, was ever the most used bible even among Campbell's own followers, it probably had a wider readership and influence than most alternative translations produced in the early nineteenth century, owing to Campbell's ecclesiastical distribution channels. It was used by Mormon founder Joseph Smith and his associates in Ohio in the 1830s and a critic in Pennsylvania noted its use in preaching there in $1839 .{ }^{6}$ By

\footnotetext{
${ }^{5}$ The best recent scholarly study of Campbell's life and work is Peter A. Verkruyse, Prophet, Pastor, and Patriarch: The Rhetorical Leadership of Alexander Campbell (Tuscaloosa: University of Alabama Press, 2005). Thomas Allen has been the subject of a dissertationEdward Feland Coffman, "Elder T.M. Allen, Pioneer Evangelist: "The Artillery of Heaven", (Ph.D. diss., Vanderbilt, 1972) - and a hagiographic monograph-Alvin Ray Jennings, Thomas M. Allen: Pioneer Preacher of Kentucky \& Missouri (Fort Worth, Tex.: Star Bible and Tract Corporation, 1977).

${ }^{6}$ For a thorough study of the theological contributions of Campbell's New Testament, see See Cecil K. Thomas, Alexander Campbell and his New Version (St. Louis, Mo.: The Bethany Press, 1958).
} 
1842, editions had been printed in Virginia, St. Louis, Cincinnati, Pittsburgh, and London, and Campbell estimated that about 40,000 copies had been distributed. ${ }^{7}$ New editions appeared periodically through the nineteenth century; the work was last printed in 1974.

Although he was a more-than-capable student of Greek (he later translated the book of Acts for the American Bible Union), Campbell did not produce the New Testament translation himself. The primary text for The Living Oracles was taken from an 1818 London edition of the New Testament which combined the work of three different translators. The Gospels were the work of George Campbell, a Presbyterian divine and a theorist of rhetoric whose work Campbell revered. ${ }^{8}$ The epistles were translated by James MacKnight, another Scottish Presbyterian. Acts and Revelation, finally, were taken from Philip Doddridge's Family Expositor, dating from the mid-eighteenth century.

Campbell became aware of this version of the New Testament when a printer in New York sent him a prospectus for issuing an American edition. Campbell subscribed for 100 copies, but the project fell through. Having the technical and financial means, he decided to take it up himself, but with important changes. Campbell thought it should sell more cheaply than the New York printer had proposed - that edition was to have been priced, depending on the binding, at $\$ 3.00$ or $\$ 2.50$, expensive for a New Testament at a time when the American Bible Society (ABS) was selling them for about twelve cents. ${ }^{9}$ Beyond price, Campbell took special care for paratexts and presentation. He thought that the volume ought to include "critical notes and amendments from other translations" and that the text "should appear in another form on the paper."10

In the context of Campbell's obsession with "the Bible alone," these concerns are surprising. We might expect a bible produced by such a thoroughgoing primitivist to be, like those of American Bible Society, shorn of the varied paratextual accretions that were attached to bibles in this period. In his own way, Campbell was in fact even more sensitive to what he called the "cluttering" of bibles than the ABS and went even further in stripping human conventions from the sacred text: in his version, he eliminated the chapter breaks and verse numbers that had been standard in English bibles since the Geneva. ${ }^{11}$ At the same time, the fourth, and what its

\footnotetext{
${ }^{7}$ Alexander Campbell, "The Bible Society and the Reformation," The Millennial Harbinger (hereafter $M H$ ) 6, no. 11 (November 1842): 521-522.

${ }^{8}$ Verkruyse, Prophet, Pastor, and Patriarch, 30.

${ }^{9}$ Gutjahr, An American Bible, Table 2.

${ }^{10}$ Campbell, "Historical Sketch of the Origin and Progress of the New Translation," MH 6, no. 3 (June 7, 1832): 268-269.

${ }^{11}$ David Daniell, The Bible in English: Its History and Influence (New Haven, Conn.: Yale University Press, 2003), 275; see also Paul Henry Saenger and Kimberly Van Kampen, The Bible as Book: The First Printed Editions (London: British Library, 1999).
} 
editor considered finally complete, edition of Campbell's New Testament contained 125 pages of non-biblical material - a full quarter of the volume. From the perspective of the ABS - always seeking a purity of the text - the addition of extensive "note and comment" was at odds with the impulse to strip the text of human additions. Campbell sought a different sort of purity, though, one which he believed was accessible through, rather than despite, biblical paratexts - a purity of understanding.

Campbell believed that complete understanding of the Bible was both necessary and possible for all Christians. Perspicuity was a requirement of revelation: "when God spoke to man in his own language, he spoke as one person converses with another - in the fair, stipulated, and well established meaning of the terms. This is essential to its character as a revelation from God; otherwise it would be no revelation, but would always require a class of inspired men to unfold and reveal its true sense to mankind." 12 At the same time, Campbell championed a Baconian rationalism which carried with it humanist assumptions regarding history and language. Campbell argued that clarity inheres as a characteristic of scripture, but he was also bound to observe that revelation came through language, a human institution subject to the vicissitudes of historical change, and through people, historical actors in particular situations. Consequently, a reader's appreciation of the clear meaning of the Bible was historically contingent. Though Campbell is routinely linked to the "common sense" reading of scripture, for him, the exigencies of language and the situational logic employed by the Bible's various authors meant that the sense of scripture was truly "common" only to its immediate, original audiences. All subsequent readers would need to make an effort to learn the art of reading scripture.

If words and phrases, and the manners and customs of mankind were unchangeably fixed, or universally the same at all times and in all countries, the art of interpreting would have been still more simple than it is: for so far as it is artificial, it is owing to different dialects, idioms, manners, customs, and all the varieties which the ever changing conditions of society have originated, and are still originating. . . The very fact that we have a written revelation, that this revelation was first spoken, then written, supposes that there is somewhere, a native or an acquired art of interpretation; that the persons addressed were already in possession of that art: for without such an understanding, there would have been neither wisdom nor benevolence, in giving to mankind any verbal communication from God. ${ }^{13}$

\footnotetext{
${ }^{12}$ Campbell, The Christian System, 3rd ed. (Bethany, Va.: A. Campbell, 1840), 15-16.

${ }^{13}$ Campbell, Connected View, 17. Campbell's views on language and the relationship of facts to faith and testimony were heavily influenced by the writings of George Campbell, whose writings on rhetoric Alexander Campbell studied at the University of Glasgow. As noted, Alexander used
} 
Campbell wrote of what he called the "understanding distance": in order to understand scripture, one must come appropriately close to it, the way one comes within speaking or hearing distance of someone with whom he or she wishes to speak. Campbell was referring to a spiritual closeness, achieved through faith and humility, but the phrase can also be applied to his sense of that "art of interpretation" which was "native" to the New Testament era and necessarily "acquired" by those of later times. ${ }^{14}$ The knowledge required for closing that distance was philological and historical: neither the original languages of the biblical documents nor the details of life in first-century Palestine were "common sense" to early-nineteenth-century Anglophone American readers.

As a bible editor, then, Campbell sought to close the understanding distance for his readers through translation and historical contextualization of the text. In keeping with his democratic sensibilities, Campbell would always argue that editorial mediation was not essential to biblical understanding: theoretically, with enough effort anyone could approach the Bible's original languages and educate themselves about its historical context. The languages were difficult, though, and those historical details were not obvious: they had to be teased out of various sources, clarified, and contextualized by wider learning. The ABS sought a purity of the English Bible text by producing bibles without note or comment, ostensibly leaving each reader to apply her own prayerful efforts in discernment of an English text whose contingency was masked. The purity of understanding that Campbell sought, however, required a thoroughly annotated printed bible.

Taken to its extreme, Campbell's insistence on historicized reading posited an ideal reader who looked nothing like the average American bible reader of the nineteenth century: a student of Greek who had collated his or her own manuscripts and studied life in first-century Palestine. This idealized potential reader is a scholar, which is an important clue to understanding Campbell's bible-editing and the nature of his claim of authority for the Bible. In short, Campbell saw his editorial work as an exercise in bringing scholarly work on the Bible to "common" readers, not as an exposition of the biblical text. He mediated between scholars and common readers, not between the authors of the Bible and common readers.

\section{Biblical Scholars AND "Common Readers"}

Thomas M. Allen was one of those readers. Born in Virginia in 1797, Allen was converted after encountering the preaching of Barton Stone about 1822 and was

George Campbell's translation of the gospels in The Living Oracles. For a detailed analysis of this influence, see Verkruyse, Prophet, Pastor, and Patriarch, 30.

${ }^{14}$ Campbell, Connected View, 17. 
active as a preacher himself, primarily in Virginia, Kentucky, and Missouri from the mid-1820s until his death in 1871. Allen was devoted to Stonehis bible records that Stone performed his wedding - and came to know Alexander Campbell when he and Stone came together to form the Disciples of Christ in the early 1830s. Allen was reasonably well-known, particularly in Missouri later in his life, and shows up infrequently in the publications of the Disciples of Christ, typically as T.M. Allen.

Though he was as adamant about taking "the Bible as [his] only rule of faith and practice" as any Disciple, the markings in Allen's bible make it clear that he did not read it "alone." 15 The influence of biblical scholarship is present all over his bible, both in printed materials that came bound with it and in Allen's handwritten notes evincing his use of other materials. Allen's bible contained a chart between the testaments, for example, one ubiquitous in eighteenthand nineteenth-century bibles, giving conversion factors for biblical units of length, weight, money, and time. On the page of his bible containing Genesis 6:15, Allen made use of the conversion factors given on the chart to calculate the size of Noah's ark, converting the cubits of God's commandment to English feet and inches. On the last page of Malachi (a common site for bible marginalia, as it typically has a large blank space), Allen wrote in cross references, chapter and verse designations for about twenty verses, connecting them to specific words in Malachi 3:16 - such compilations clearly suggest the use of a concordance. Allen made similar lists in a few other places.

Most significantly, Allen's bible heightens the irony of Campbell's editing of the New Testament: in his pursuit of full, direct understanding of the Bible, Allen made extensive use of Campbell's scholarship. At the head of each book of the New Testament, as well as a few of the prophets, Allen wrote in a year and often a place of composition; for the New Testament epistles, he also included the addressee. He also made his own little chart of this information for the New Testament on a back flyleaf. In Allen's day, scholarship was unsettled with regard to the dates of authorship of the New Testament books. For the Gospel of Matthew, for example, scholars posited dates ranging from A.D. 36 to 64; some German scholars were beginning to suggest, as almost all modern scholars now accept, that Matthew was not the earliest Gospel and that it dates from the last two decades of the first century. Allen was at least somewhat aware of the disagreements with regard

\footnotetext{
${ }^{15}$ Allen's bible is a small duodecimo published by Silas Andrus at Hartford, Connecticut in 1828 from stereotyped plates by J. Howe of Philadelphia. It has been re-bound - the original cover and binding are lost, but the book is otherwise intact. It has Allen's signature in the top left corner of the title page; I have matched it to those on Allen's letters at the University of Kentucky. Likewise, the handwriting and the details of the genealogical material match Allen's. The book's accession record indicates that it came to Chicago from Louisville in 1913 as part of the Reuben T. Durrett collection.
} 
to the dates of the New Testament books. His bible contained a chart giving the dates of composition of the New Testament texts compiled by Princeton president John Witherspoon. First printed in 1790, Witherspoon's chart was reprinted in countless nineteenth-century bibles, but by Allen's day it had been superseded by more recent scholarship. Allen ignored Witherspoon's chart. The dates he wrote into his bible instead come from a chart Campbell included in The Living Oracles, specifically from the first or second edition. ${ }^{16}$

Thomas Allen was a particularly vitriolic participant in the routine mocking of "DD's" in early Disciples publications - he used "doctor" as an epithet and once suggested that a Presbyterian minister he heard cite Doctor of Divinity Thomas Scott may as well "quote the Pope of Rome" to make his case. ${ }^{17}$ Campbell, though, while adamant that explaining the Bible would not require a "class of inspired men," did not deny that it required scholars: he identified the three translators whose work he compiled in The Living Oracles as "Doctors" on the title page. Allen's use of The Living Oracles demonstrated that while he was avowedly less comfortable with scholarship than Campbell, he nevertheless shared Campbell's commitment to the historicity of scripture. Allen's marginalia indicate that he observed Campbell's oft-repeated first rule of bible reading, which held that when a reader opened a text of scripture, he or she must "consider first the historical circumstances of the book. These are the order, the title, the author, the date, the place, and the occasion of it." 18 This type of historical imagination manifested in Allen's obsessive need to date the New Testament books, as well as in his effort to calculate the size of Noah's ark using the chart in his bible. The chart had an historicizing influence: it allowed Allen to think of the ark as a thing with dimensions, just like a barn or a home. Allen was not going to come upon those details of the Bible which Campbell said were essential on his own, because they were either not present in the text or not readily apparent to common readers of "the Bible alone." The historical and historicizing details that made possible the kind of reading Allen was committed to were provided by the type of authorities he railed against.

\footnotetext{
${ }^{16}$ All of Allen's years match Campbell's, and no other single source, and their phrasing - “first published in Judea AD 41" for Matthew, for example, comes verbatim from The Living Oracles, where it appears at the heading of the "Testimony According to Matthew." ("Testimony," Campbell's term in place of "Gospel," is present throughout Allen's notes, another place where Campbell's influence is plainly evident.)

${ }^{17}$ Christian Messenger (Georgetown, Kentucky) 4 (December 1830): 279-283; reproduced in Jennings, Thomas M. Allen, 203.

${ }^{18}$ Campbell, The Christian System, in Reference to the Union of Christians, and a Restoration of Primitive Christianity (Pittsburgh, Pa.: Forrester \& Campbell, 1840), 16. See also Connected View, 96.
} 


\section{The Stakes of Editorial Authority}

The acknowledgment that contemporary Bible understanding required instruction-that what was rendered as transparent truth by God now required gloss - was the tension at the heart of early Disciples' wide-ranging engagement with biblical authority. Campbell's work on the New Testament was controversial, beginning at the level of the translation itself. Campbell started with the work of the three scholarly translators, and they are credited with the translation on the title page, but he made countless edits to their work. These were enough for his critics to claim that the preponderance of the work was actually his own and that he was passing it off under the names of the three scholars to enhance the text's authority. It is clear from simple comparison that the core of the text was unaltered (as Campbell claimed), but there is also no mistaking the fact that The Living Oracles is emphatically "Campbell's New Testament," which is indeed what many people called it. ${ }^{19}$

Despite his historically-grounded approach to language, Campbell had complete confidence that the problems of translation could be overcome. Because the Bible was originally written according to the commonlyaccepted language of given places and times, it could be translated by the same principles into the language of a different place and time. "The English, or German, or French 'New Testament,' is as much the word of the Spirit as the Greek original, if that original is faithfully translated."20 Translations could be faulty, however, in two ways. They could be outdated, owing to "constantly fluctuating" living language, or they could be inherently warped, as a result of translator error, use of flawed manuscripts, or deliberate subterfuge.

Campbell laid all of these forms of error on the King James. While there were many "new" English bibles in America in the early nineteenth century, there was only ever one "old" one, and all promoters of new versions felt the need to position their work against the King James. Directly preceding the first publication of The Living Oracles, Campbell ran a series of articles on "the history of the English Bible" in the Christian Baptist, his magazine at the time, culminating in a piece which argued that the Authorized Version was

\footnotetext{
${ }^{19}$ Beth Barton Schweiger has pointed to the paradox of Campbell's primitivist convictions in an article exploring his obsession with print. Campbell, she writes, "embodied the contradiction of the Protestant preacher and printer, one that lay at the heart of his restorationist doctrine. By directing his reader's attention to the Scriptures, he drew attention to himself as the one pointing to them. By denying the necessity of interpretation, of merely pointing out the plain meaning of the text, Campbell asserted his authority over readers who would apparently recognize the truth only with his help." "Alexander Campbell's Passion for Print: Protestant Sectarians and the Press in the Trans-Allegheny West," Proceedings of the American Antiquarian Society (2008), 129.

${ }^{20}$ Campbell, Connected View, 21.
} 
hopelessly subject to translation errors and deliberate obfuscation. Campbell promised something better: "To remedy those evils, so long and so justly complained of, we have issued proposals for publishing a new translation of the New Testament, made by Doctors Campbell, Macknight, and Doddridge, decidedly the best that has appeared in our language." 21 No one of those translators solved all of the problems, though, and so as a solution to the problems of the King James, The Living Oracles was the creation of Campbell's heavy editorial hand.

Campbell's positioning of The Living Oracles against the King James continued in the "General Preface" to the work, where he focused on the King James Version's outdated language. Campbell mocked the widespread devotion to King James English as inherently sacred: "Our whole phraseology on religious topics is affected by the antiquated style of the common version. . . . This old fashioned style we call 'the sacred style.'yet this sacred style was the common style in the reign of James." ${ }^{\text {,2 }}$ By contrast, his translators - products of late-eighteenth-century England and Scotland-used more contemporary English. At Acts 26:14, for example, Doddridge changed the King James's "kick against the pricks" to "kick against the goads"; "prick" was one of those earthy King James words that later English speakers found out of place in their bibles. Thomas Allen absorbed this change - in an 1838 letter to his friend John Allen Gano, he applied that verse to some people in his own life and used "kick against the goads." ${ }^{23}$ This kind of change didn't suit everyone, though. The publishers of an 1848 London edition of The Living Oracles observed that abandoning thou, thee, and thy for you and similar changes had the effect of "robbing the New Testament of its pure old Saxon style, and also of that degree of reverence which so beautifully characterizes the "Word of God." They thought it scandalous to address the Savior as "You" and corrected for Campbell's informality. ${ }^{24}$

Matters of doctrinally-significant translation loomed larger. The most conspicuous idiosyncrasy in terms of word choice in The Living Oracles concerns $\beta \alpha \pi \tau i \zeta \omega-$ "baptizō" and related words. Tradition cited by Campbell held that James I himself had forbade his translators to translate

\footnotetext{
${ }^{21}$ Campbell, "History of the English Bible-No. IV," The Christian Baptist 2, no. 11 (June 6, 1825): 161

${ }^{22}$ Campbell, ed., The Sacred Writings of the Apostles and Evangelists of Jesus Christ, Commonly Styled the New Testament, 2nd ed. (Bethany, Va.: Alexander Campbell, 1828), 448.

${ }^{23}$ Thomas M. Allen to John Allen Gano, August 18, 1838, University of Kentucky Archives. They were not all equal in this respect, though. Campbell complained (with considerable justice) that Doddridge's work was often verbose and clumsy, and comparison shows that he freely edited Doddridge's Acts and Revelation to make them more readable.

${ }^{24}$ Campbell, ed., The Sacred Writings of the Apostles and Evangelists of Jesus Christ, commonly styled the New Testament (London: Simpkin, Marshall, and Co., 1848), vii.
} 
these and other "old ecclesiastical words," committing the cardinal sin, in Campbell's view, of forcing their work to conform to pre-existing doctrinal commitments. ${ }^{25}$ The resulting "no-translation" (as opposed to mistranslation), as Campbell called it, prevented English readers from recognizing that Christ mandated believers" "immersion." Campbell's concern for the proper authority for the Bible shone clearly here: "But who said those words were consecrated and ecclesiastical words, which should not be translated? The king and ecclesiastics, whose practice required this pious fraud to justify their kind of baptism, or at least to conceal that their practice was unscriptural." These authorities were, needless to say, insufficient to impress Campbell. Translation must be a disinterested academic exercise. What is notable, though, is that none of Campbell's three scholarly translators used "immerse" for "baptize" as often as he would have liked, which was in every possible instance. Comparison shows that Campbell changed "baptize" and related words to "immerse" throughout the translations. George Campbell, as a Presbyterian, did not use the word in his rendering of the Gospels at all; in Alexander's version of George Campbell's text, it appears so consistently as to refer, rather awkwardly, to "John the Immerser" at every opportunity.

Campbell's assertion of authority over the translation grew in strength over the course of the early editions. The first and second editions contained a lengthy appendix of divergent translations of difficult passages, crossreferenced from the text. This was in the service of transparency - the reader would be able to glean the shades of Greek meaning of a difficult passage without actually knowing Greek, through a collation of learned translators' choices. "We have given the most conspicuous place to that version which appeared to deserve it," Campbell wrote, "but as the reader will have both, we have not judged for him, but left him to judge for himself." ${ }^{26}$ After the third edition, Campbell went ahead and judged for the reader. He removed the appendix giving the long list of parallel translations and struck the disclaimers from the "General Preface." The appendix for the third edition still included a Table XIV giving "principal Greek terms yet in controversy" and some various translations for them, but even this is omitted from the fourth edition.

The most controversial changes which Campbell made to the work of the three translators stemmed from manuscript issues. None of the three translators had used the Greek New Testament collated by German biblicist Johann Jakob Griesbach, first published 1775-1777, which Campbell

\footnotetext{
${ }^{25}$ In the November 1, 1824, issue of the Christian Baptist, Campbell printed extensive extracts from John Lewis's A Complete History of the Several Translations of the Holy Bible, and New Testament, into English, both in MS. and in Print, probably from the 1818 London edition.

${ }^{26}$ Campbell, ed., The Sacred Writings of the Apostles and Evangelists of Jesus Christ, commonly styled the New Testament (Buffaloe, Brooke County, Va.: Alexander Campbell, 1826), xiii.
} 
considered to be the best possible source text. Modern scholars credit Griesbach (1745-1812) with laying the foundations for modern scholarship on the Greek manuscripts of the New Testament. ${ }^{27}$ Griesbach travelled extensively to compare extant Greek manuscripts of New Testament texts, and made judgments about the most likely original text based on interpretive principles that took into consideration quotations used by the church fathers and the transmission history of the manuscripts. On the strength of Griesbach's scholarly acumen, Campbell found this work completely persuasive. "The world is, perhaps, more indebted to this learned and distinguished professor and critic, than to any other critic on the long list of collators, interpreters, and editors of the New Testament," he wrote. ${ }^{28}$

In the first and second editions, Campbell wove this critical text into the work of the three translators by italicizing most words and phrases Griesbach deemed spurious. As with the parallel translations, though, Campbell's assertion of authority over the spurious passages grew stronger in the later editions, where they were deleted in the body of the text. He deleted most of the passages italicized in the first two editions and removed the italics from those which he kept, removing what had been considered scripture and eliminating the typography through which he had marked some parts of the text as more reputable than others. The deleted passages were noted in a new appendix. The 357 deleted passages were numbered sequentially, as if at some point there was a plan to reference them in the text, but no such references are present in the third and subsequent editions-within the text itself, the questioned passages are silently removed. Campbell viewed this as the apogee of a scholarly approach to scripture, but it incensed his critics and alienated some readers. R.W. Landis, author of the most thorough and most bitter critique of The Living Oracles, was rendered speechless: "We cannot trust ourselves to speak the sentiments we entertain of such atrocious treatment of the word of God." ${ }^{29}$ In 1827, Campbell reported, with what reads like both exasperation and glee, that a copy of The Living Oracles had been publicly burned in Jessamine County, Kentucky. ${ }^{30}$

Many did not find Griesbach's authority as a scholar sufficient to warrant the deletion of material that had been regarded as inspired for centuries. "There can be no doubt," Landis conceded, "that some few errors have crept into the Greek text of the New Testament. But then neither Professor Griesbach, nor any other

\footnotetext{
${ }^{27}$ Bruce M. Metzger and Bart D. Ehrman, The Text of the New Testament: Its Transmission, Corruption, and Restoration, 4th ed. (New York: Oxford University Press, 2005), Part II, chap. 4.

${ }^{28}$ Campbell, $M H$, extra no. 11 (October 1839): 522.

${ }^{29}$ R. W. Landis, "Campbellism," The American Biblical Repository, Second Series, no. 11 (April 1839): 318.

${ }^{30}$ Christian Baptist 4, no. 9 (April 2, 1827): 326. For more on controversy around The Living Oracles, see Gutjahr, An American Bible, 105.
} 
person, is yet able, from the data which we have, to point them out with sufficient certainty to justify our rejection of any portion of Scripture." 31 Campbell did not deign to defend individual deletions, but his preface to the fourth edition makes a characteristic appeal to scholarly consensus: "Some, indeed, appear to be rejected without a very overwhelming authority; but all, I think, have more than a bare majority of votes regarding both number and character, against their standing in the text. ${ }^{, 32}$

Campbell presented his treatment of spurious passages as allegiance to the scholarship of Griesbach, but his own judgments loomed large. Griesbach, for instance, gives a lengthy footnote on the Markan Coda (Mark 16:9-20, widely thought by modern scholars to be a late addition to the text), but Campbell let it stand without comment. ${ }^{33}$ This is possibly owing to the rather ambivalent ending which cutting it off gives to the text- "neither said they any thing to any man; for they were afraid"-or, possibly, because Campbell appreciated the risen Christ's specific endorsement of "immersion" in $16: 16$.

At the same time, Campbell was willing to eliminate verses that helped his particular theological positions in deference to Griesbach's scholarship. Acts 8:37, the confession of the Ethiopian eunuch, was a text with significance for Campbell's side of the intra-Baptist argument over the terms of believer's baptism. Campbell and like-minded reformers argued that baptism should be granted to anyone making a simple confession of faith, while other Baptists were convinced that the new believer must narrate a conversion experience. In Acts 8:37, Philip's baptism of the eunuch is connected to a simple statement of faith, supporting Campbell's side of the argument: "The eunuch said, See, here is water; what doth hinder me to be baptized? And Philip said, If thou believest with all thine heart, thou mayest. And he answered and said, I believe that Jesus Christ is the Son of God." Griesbach, however, found the verse spurious, and Campbell removed it.

\section{Unbroken Time: The Bible in/As History}

Tellingly, Thomas Allen did not follow Campbell in abandoning Acts 8:37. In Allen's bible, the verse is marked with the curling lines he evidently used to mark passages of particular interest or import, looping brackets which explicitly connect the verse to those before it, rather than cut it off from

\footnotetext{
${ }^{31}$ Landis, "Campbellism," 325.

${ }^{32}$ Campbell, ed., The Sacred Writings of the Apostles and Evangelists of Jesus Christ, commonly styled the New Testament, 4th ed. (Bethany, Brooke Co., Va.: M'Vay and Ewing, 1835), Appendix p. 30 .

${ }^{33}$ See Thomas, Alexander Campbell and his New Version, 37.
} 
among them. Beyond that, documentary evidence records that Allen had a particular regard for Acts 8:37. In his journal, John Allen Gano recorded Allen's participation in a moving scene of baptism focused around the exchange between Philip and the eunuch:

On Lord's day 16th [of September, 1827] Bro Allen again preached and afterward immersed Mrs. Williams, as she came up out of the water her mother (Mrs. Mary T. Webb) approached bro Allen[:] "here is water" said she "what hinders me from being baptized"; "If thou believest thou mayest" answered he, "I believe that Jesus is the Christ the Son of the Living God," she replied he then straightway immersed her[.] Truly thought I this looks like the case of Philip and the eunuch. ${ }^{34}$

No amount of German scholarship could discourage a preacher like Allen from responding to the Ethiopian's question with Philip's response when the opportunity presented itself so neatly. It is precisely moments like this that have led scholars to characterize Disciples and other primitivists as beholden to an ahistorical reading of scripture. Richard T. Hughes and C. Leonard Allen, following Dwight Bozeman's work on the primitivist strain in Puritan thought, have gone so far as to apply Mircea Eliade's terms to suggest that restorationists such as Stone and Campbell operated within a framework of sacred versus profane time. Sacred time, as explained by Eliade, is "reversible," "indefinitely recoverable, indefinitely repeatable," "a sort of eternal mythical present that is periodically reintegrated by means of rites." ${ }^{\prime 35}$ This "primordial" time is treated as a model for the present, one that can be repeated because it exists outside of history. By this logic, Allen and Mary Webb, trading lines from Acts, were repeating a timeless scene of confession and baptism. ${ }^{36}$

As has been discussed, though, Allen was conscious of the Bible's historical specificity. As Campbell instructed, he paid careful attention to the historical origins of the biblical texts and made an effort to think about practical details

\footnotetext{
${ }^{34}$ Notebook of John Allen Gano, University of Kentucky archives.

${ }^{35}$ Mircea Eliade, The Sacred and The Profane: The Nature of Religion, trans. Willard R. Trask (New York: Harcourt Brace Jovanovich, 1987), 69-70. See also Richard T. Hughes and Leonard Allen, Illusions of Innocence: Protestant Primitivism in America, 1630-1875 (Chicago: University of Chicago Press, 1988); Theodore Dwight Bozeman, To Live Ancient Lives: The Primitivist Dimension in Puritanism (Chapel Hill: University of North Carolina Press, 1988).

${ }^{36}$ The equation of primitivist ecclesiology with the appeal to primordial, rather than historical, time as suggested by Hughes and Allen has become a scholarly commonplace. See, for example Monica Najar, Evangelizing the South (Oxford: Oxford University Press, 2008), 34-35; James Bratt, ed., Antirevivalism in Antebellum America (New Brunswick, N.J.: Rutgers University Press, 2006), xv; and David Manning, “"That Is Best, Which Was First': Christian Primitivism and the Reformation Church of England, 1548-1722," Reformation \& Renaissance Review 13, no. 2 (November 4, 2011): 153-193. Manning's is a nuanced study of primitivism in the English Church which nevertheless tacitly assumes the relevance of the Eliadean primordium to primitivist thought.
} 
like the size of Noah's Ark. Viewed as the sourcebook for early Christianity, the New Testament becomes an historical document, and the effort required to contextualize the New Testament documents, in order to interpret them correctly, becomes an act of historical imagination.

Hughes and Allen linked Christian primitivism to an American impulse toward the recovery of an ideal era, an exemplary past outside of time. "Most Americans were not concerned to recover their recent past, or even an ancient past which was merely history, fully as corrupt and degenerate as the recent past from which they had sprung," they wrote. "But they were concerned to recover the primordial past that stood behind the historical past." 37 Hughes and Allen took pains to explain the difficulty of ascribing ahistorical impulses to a form of Christianity, which Eliade himself plainly labeled an historical religion inasmuch as it "affirms the historicity of the person of Christ." 38 They describe a point of historical fidelity at which Christians, while revering the Incarnation as an historical moment, come to fetishize a past which is something other than history and which may be relived rather than merely re-enacted. "When the normative history is swallowed up in myth to such an extent that the believer loses the clear distinction between his own time and the primal time, then that historic tradition has lost its historicity. At that point, the particular time that was merely normative now has become the eternally repeatable primordium within which the believer lives and moves and has his being apart from which life itself has no meaning or significance." 39

Hughes and Allen suggest that Disciples, as exemplars of nineteenth-century Christian primitivism, reached such a point, finding a "sense of historylessness" to be the "heart of restoration thinking." 40 While in terms of idealizing the New Testament era there is something to this, what such approaches to primitivism miss is the radically historicized nature of restorationist readings of the Bible as the sourcebook for that "primordial" past. However Eliadean ideas of sacred and profane time may apply to other religious traditions, they obscure essential elements of nineteenth-century restorationism which a more text-based approach illuminates. For early Disciples, the Bible did not concern an exemplary past outside of time, but rather documented specific, historically and geographically locatable, and avowedly irrepeatable events. "The Bible is a book of facts," Campbell wrote, "not of opinions, theories, abstract generalities, nor of verbal definitions." A1 A good Baconian, Campbell's definition of "facts" was

\footnotetext{
${ }^{37}$ Hughes and Allen, Illusions of Innocence, 2.

${ }^{38}$ Ibid., 72 .

${ }^{39}$ Ibid., 5-6.

${ }^{40}$ Ibid., 207.

${ }^{41}$ Campbell, The Christian System, 18.
} 
nothing but historical, and he distinguished them from "truths" specifically by their location in time: "Fact means something done." 42 Most of the Bible, moreover- "exactly four-fifths" in Campbell's estimation-is taken up with the relation of facts. "History is therefore the plan pursued in both Testaments," Campbell argued. ${ }^{43}$

The Living Oracles' paratexts bear this out. The third and fourth parts of Campbell's appendix are a "Geographical Index" connecting the New Testament events and personalities to the world map and a numbered timeline of the common sort attached to nineteenth-century bibles, mapping the events of the New Testament onto world history. They are not the work of a man committed to the idea of a New Testament primoridum outside of space and time.

Crucially, this commitment to the historicity of the biblical era, quite distinct from an appeal to a mythical primordium, is carried through in Campbell's sense of contemporary Christians' relationship to the early church. Simply put, for Campbell the biblical era is temporally and geographically distant, and therefore irreducibly distinct, from nineteenth-century America. In one of his prefaces to the epistles, for example, he railed against their traditional theological use by reminding the reader that "these letters were written nearly eighteen centuries ago." This fact means two important things for the reader. In terms of interpretation, "excepting the prophetic part of these writings, not a word or sentence in them, can be explained or understood, by all that has happened in the world, for eighteen hundred years." In terms of application, the contextual differences between his readers' time and that of the apostles cannot be collapsed: "As the Apostles did not write, with any of our questions before their minds, or with a reference to any of our systems, it is presumptuous in the extreme, to apply what they have said on other questions, to those which have originated since." 44 The New Testament should be the sole source of contemporary faith and practice, but its distance from our own time and place necessitates an effort in understanding it. Bible reading begins with history.

Campbell enumerated several authoritative sources from which historical context could be gleaned. First and foremost, like others, Campbell primarily emphasized scripture as its own interpreter: each text itself gives clues to its circumstances of production. The book of Acts, further, provides an historical overview of the period in which most of the letters were produced, intimating some of the same scenes: "This book is the grand link, which connects the previous histories with the epistles, and constitutes the key to

\footnotetext{
${ }^{42}$ Ibid., 110.

${ }^{43}$ Ibid., 18.

${ }^{44}$ Campbell, ed., The Sacred Writings of the Apostles and Evangelists of Jesus Christ (1835), 26.
} 
the right interpretation of them; without which they would have been, in a great measure, unintelligible. ${ }^{25}$ The Old Testament, further, contains prophecieswhich Campbell, incidentally, considered a form of history — of New Testament events which can illuminate the historical documents.

Moreover, Campbell was in no way opposed to applying "extrinsic sources of information" to the Bible. His philological concerns on some level required it - the precise meanings of the words and phrases of the original Greek could be found only by analysis of their use in other contemporary sources. Table XI of Campbell's appendix, which explains idioms found in the New Testament according to "ancient usages, manners, and customs," is the clearest illustration of this use of extra-biblical sources to establish historical context. ${ }^{46}$

The most obvious aids to the reader which Campbell provided had to do with re-establishing the genres of the various New Testament texts in service of historicizing them. The Bible is composed of texts that fall into a wide range of genres - narrative, genealogy, first-person visionary account, poetry, letter, or often some combination of these. In the typical King James layout, however, norms of presentation and paratextual addition conspire to suppress these designations. The standard chapter and verse divisions of English bibles ultimately go back to the Vulgate edition produced by Sanctes Pagninus in 1527 and the 1551 Greek New Testament of Robert Stephens. ${ }^{47}$ The editors of the Geneva Bible were the first to begin each verse on its own line, a layout that the King James translators adopted and which became standard in English bibles. In terms of genre, this might suit Psalms and Proverbs as poetry and aphorism, but the overall effect is to eliminate the sense that some of the biblical texts are doing different things than others; particularly when cross-references, chapter summaries, and guide phrases are added, the Bible's multiple genres appear on the printed page as a new, now immediately identifiable genre: "scripture." The New Testament epistles look like the Bible, not like letters.

Campbell believed that when the paragraphs of a narrative or a letter were "chopped," "minced," and "crumbl[ed]" into verses (as John Locke complained, in a passage cited by Campbell), the original sense of the text was lost as every line became its own "independent aphorism." "The reader must recollect that no one sentence, in the argumentative part of a letter, is to be explained as a proposition, theorem, proverb, or maxim, detached from the drift and scope of the passage., ${ }^{49}$ Allen and other Disciples ministers made a habit of ridiculing the traditional ministerial

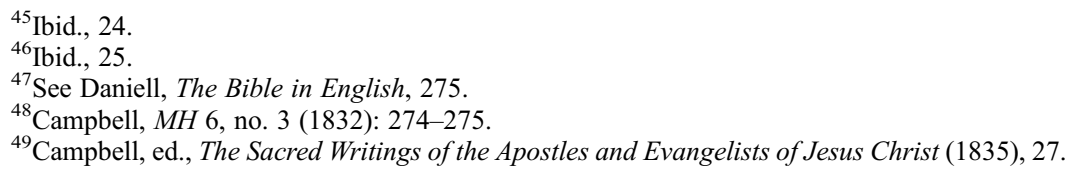


practice of preaching on a given verse or portion of a verse of scripture: what Methodists referred to as "taking a text" they termed "scrap preaching." 50

Accordingly, Campbell eliminated the standard verse numberings throughout The Living Oracles, forming the texts into paragraphs. In the Gospels, Campbell adopted the sense-oriented section breaks and brief headings used by George Campbell, which he found appropriate for works of history. Rejecting Doddridge's section breaks and headings for Acts and Revelations, Campbell created his own for the former and presented the latter in paragraphs, with Roman numerals giving the standard chapter numbering. ${ }^{51}$ Campbell stripped the epistles of chapter breaks and in-line verse numbers completely-such divisions made no sense for letters, he argued. Throughout, Campbell included occasional verse and chapter numbers at the beginnings of paragraphs to assist readers in finding their place with respect to conventional bibles. In the first and second edition these are sparse. "To checker the margin with a column of figures marking every verse in the common version, appeared no way profitable to the reader," Campbell wrote. "It rather perplexes the eye and distracts the attention of the reader, as well as dislocates the sense, and perpetuates what ought soon to be forgotten." ${ }^{.52}$ In response to reader complaints - he reports that they had been "much called for by many readers"-Campbell relented for the third edition, in which nearly every verse is numbered in the margin. ${ }^{53}$ For the fourth, stereotyped edition, Campbell went back to more selective numbering.

With respect to genre, Campbell felt very strongly about titles, as well, because a title "sometimes expresses the design of the book," giving insight into the all-important intention of the author. ${ }^{54}$ Although Campbell noted that "in most of the Greek copies" Acts is titled "The Acts or Transactions of the Apostles," this name conflicts with the contents of the book. "Acts of Apostles" is more proper, he wrote, since "only a few transactions of a few apostles are mentioned in it." ${ }^{, 5}$ Campbell also insisted that the Gospels be titled "testimonies"- "The Testimony of" rather than "The Gospel According to"- because they are works of eye-witness history rather than simple statements of belief. "All of these histories testify thousands of items, which, though subservient to their main design, are different from, and not the gospel of Jesus Christ, properly so called," Campbell wrote. ${ }^{56}$

\footnotetext{
${ }^{50}$ See, for example, Thomas M. Allen in the Christian Messenger (Georgetown, Kentucky) Vol 4 (December 1830), 185-187; reproduced in Jennings, 197-200.

${ }^{51}$ Thomas, Alexander Campbell and his New Version, 27-28.

${ }^{52}$ Campbell, ed., The Sacred Writings (1828), xii.

${ }^{53}$ Campbell, ed., The Sacred Writings (1835), 49.

${ }^{54}$ Campbell, The Christian System, 16.

${ }^{55}$ Campbell, ed., The Sacred Writings (1835), 23.

${ }^{56}$ Campbell, ed., The Sacred Writings (1828), 391.
} 
Campbell's obsession with genre opens onto what he repeatedly emphasized as the most important requirement for coming into the understanding distance - obtaining knowledge of each author's purpose in writing each text: "No person can be said to fully understand what is written in it, unless he know [sic] why it is written." ${ }^{57}$ Campbell wrote prefaces or "prefatory hints" for the Gospels, Acts, each epistle through James, and Revelation; he quoted MacKnight's prefaces for the remaining letters. These editorial introductions are dominated by his concern to make each author's purposes plain to the reader. At a basic level, Campbell followed pretty much every Christian commentator before him in acknowledging the rule of faith as the primary purpose of the New Testament documents: their essential purpose was to witness to readers that "Jesus the Nazarene is the Son of God, the Saviour of men." 58 As indicated by his preference for "Testimony" over "Gospel," though, Campbell's radically historicized view of the New Testament documents obligated him to observe that each text was also an artifact of immediate, historically-situated purposes of a human author. The overall purpose of revelation - witnessing to Christ - might be unchanging, but these immediate purposes were discrete and contextual: "Now, it requires not a moment's reflection, to see that Paul had one design in writing to Timothy, another in writing to Philemon, and another in writing to the congregation in Rome." ${ }^{59}$ These situational differences were particularly evident with regard to the epistles, but they applied in the same way to the Gospels. Matthew wrote for "his countrymen, the Jews," and so he emphasized Jesus's Davidic lineage, while John, writing "at a great distance from Judea, . . . would not think of troubling [his audience] with a roll of lineage about [Jesus's] pedigree." $" 60$

Campbell's historicized approach to the Bible led him to show the characters and authors of the New Testament to be historical, human presences. Understanding these presences was a required part of understanding their textual productions: "Now, as the design of a writer is his own guide in the selection and arrangement of his materials, arguments, and evidences; so is it the only infallible guide, when known, to the interpretation of what he has written." ${ }^{61}$ As human beings, the apostles can have human motivations. Paul's goals in 1 Corinthians, for example, were "to support his own authority, dignity, and reputation; to vindicate himself from the aspersions and calumnies of the factious; and to diminish the credit and influence of those aspiring demagogues and leaders. ${ }^{" 62}$ The authors can also be imagined

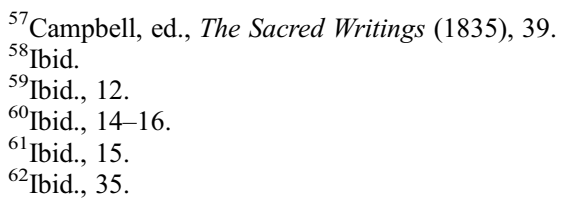


to be limited in their knowledge - not of the Gospel, but of their historical circumstances. Paul, for example, wrote to the congregation at Rome "according to the best information he had respecting them, not having been himself at Rome." ${ }^{\prime 3}$ Campbell posits that Matthew, wishing to recite the lineage of Christ to his Jewish audience, "would apply to the Registrar's office, for a copy of the roll of the lineage of the house of David, well attested; and from this, trace Jesus to David."

This kind of historical reconstruction of the life of an evangelist is an act of imagination that is distinctly different than the imaginative conjuring of an ideal time outside of time-surely there are no registrars in Paradise. Nevertheless, while Campbell worked to reconstruct an historical moment in which the events of the New Testament took place and were recorded, he stopped short of rendering the actors involved as fully-realized human beings. These historians cannot concoct, they can only make choices about which truths to tell and emphasize. They did not shape their histories so much as arrange them. Campbell quotes MacKnight - himself a renowned professor of rhetoric - to emphasize that despite the necessity of communication strategies, when the New Testament authors write, "every thing is told naked and unadorned, just as it happened." ${ }^{\prime 65}$

This is the tension that has led historians to miss the historicizing impulse at the core of primitivist thought: for Campbell, the biblical texts had to both have a history and transcend it. Moreover, it wasn't just the evangelists and apostles whom Campbell believed transcended their historical situations. Just as the authors of the New Testament were human actors who both formed scripture according to their own lights and served as perfect conduits for revelation, Campbell believed that later scholars could make scripture understood by dint of their personal qualities. He wrote of the three translators whose work he incorporated into The Living Oracles as examples of those rare scholars, appearing "once or twice in a hundred years," "whose literary acquirements, whose genius, independence of mind, honesty, and candor, may fit them to be faithful and competent translators." $"$ Campbell emphasized his debts to these scholars - "We stand on the shoulders of giants"- but could not avoid placing himself in their line: "Like the wren on the back of the eagle, we have as large a horizon as the eagle, which has carried us above the clouds." ${ }^{, 67}$ Critics noticed this. "Mr. Campbell," Landis wrote, "is determined not to submit to the inconvenience of waiting, as other authors are compelled to, till the tardy public utter forth their praises of his productions.

\footnotetext{
${ }^{63}$ Ibid., 30.

${ }^{64}$ Ibid., 14-15.

${ }^{65}$ Ibid., 22.

${ }^{66}$ Ibid., 6.

${ }^{67}$ Ibid., 46.
} 
He has acquired the art of self-praise, and extols himself, and his works still more." 68

Campbell saw himself as an interested editor who took a heavy hand with the text, and yet offered readers unmediated access to it. What was timeless for Campbell, really, was as much a scholarly commitment as a religious one: the impulse of the Bible's various human handlers to provide readers a transparent understanding of whatever the Bible was imagined to be. Campbell understood the apostles' and evangelists' composition of the New Testament, Griesbach's collation of manuscripts, the translation work of George Campbell, Doddridge, and MacKnight, and his own editing of it as one historical thread. At each point the words might change, but the commitment to transparent understanding was eternal.

${ }^{68}$ Landis, "Campbellism," 316. 